\title{
Organic Richness and Organic Matter Quality Studies of Shale Gas Reservoir in South Sumatra Basin, Indonesia
}

\author{
Jamaluddin, Fuqi Cheng \\ Geological Engineering Department, School of Geosciences, China University of Petroleum (East China), Qingdao, China \\ Email: jamaljamaluddin1994@gmail.com, chengfuqi@upc.edu.cn
}

How to cite this paper: Jamaluddin, \& Cheng, F. Q. (2018). Organic Richness and Organic Matter Quality Studies of Shale Gas Reservoir in South Sumatra Basin, Indonesia. Journal of Geoscience and Environment Protection, 6, 85-100. https://doi.org/10.4236/gep.2018.612006

Received: October 14, 2018

Accepted: December 11, 2018

Published: December 14, 2018

Copyright ( 92018 by authors and Scientific Research Publishing Inc. This work is licensed under the Creative Commons Attribution International License (CC BY 4.0).

http://creativecommons.org/licenses/by/4.0/

\begin{abstract}
Talang Akar Formation is a proven hydrocarbon source rock in South Sumatra basin. The formation contains dominant shale at the top, with some sandstone interbeds. Whereas it contains coarse to very coarse sandstone beds at the bottom. The lower sandstone unit also contains carbonaceous shale and some coal seams. The geochemical analysis is important to identify a source rock quality in shale gas. The quality of source rock is determined by richness of the source rock and type of kerogen. 37 samples were collected from well cuttings in JML-1 and JML-2 wells. Samples we are received into the laboratories in the form of well site canned ditch cuttings, bagged ditch cuttings in various stages of preparation from wet, unwashed to dried, washed; sidewall cores, conventional cores, outcrop samples. The richness of a source rock can be defined by the content of organic carbon which is measured as total organic carbon (TOC). Based on geochemical result of analysis, quantity of shale hydrocarbon potential is indicated by the TOC value of $0.52 \mathrm{wt} \%-6.12$ wt\% (fair to excellent criteria), with average of shale thickness more than 50 $\mathrm{m}$. Tmax is an indication of the maturation stage of organic material and Hydrogen Index (HI) is a parameter used to explain the origin of organic material. HI versus Tmax crossplot was analysed for kerogen type determination and presence of type II/III kerogen was identified. This study concludes that the source rock contains abundant humic organic matter that was deposited in a transitional (Fluvio-deltaic) to marginal marine environment under oxic conditions.
\end{abstract}

\section{Keywords}

Organic Matter, Organic Richness, Shale Gas, South Sumatra Basin, Talang Akar Formation 


\section{Introduction}

Shale Gas is a natural gas bound in very small pores of shale that cannot be produced by conventional gas. The essential parameters to be considered for shale gas prospect evaluation are total organic carbon (TOC), thermal maturity, kerogen type, thickness, depth, depositional environment, porosity, permeability, pressure, mineralogy, clay content and geomechanical properties. The potential of the source rock locally is also found in the marine shale of the Gumai Formation; some wells in the northern basin have been reported to have TOC values up to $8 \%$ and $\mathrm{HI} 350 \mathrm{mg} \mathrm{HC} / \mathrm{g}$ (Courteney et al., 1990). Based on estimation from well logs, it is possible to indicate the presence or absence of good quality source rocks in Talang Akar Formation. Geochemical data become important parameters in gas shale study. The shale should meet two conditions, as source rock and as reservoir. The quality of source rock is determined by richness of the source rock, type kerogen, and maturity of source rock. The richness of a source rock can be defined by the content of organic carbon which is measured as total organic carbon (TOC). The amount of organic carbon present in rock is not only important as a source rock but it also contributes to the natural gas storage by adsorption and/or solution within the reservoir system. In the play concept of shale gas, using the shale-gas data that have been successful in US, the minimum average TOC value required is $>2$. The minimum value of shale-gas TOC is different from the conventional play concept (Peters \& Cassa, 1994).

Second geochemical parameter for gas shale is kerogen type. Kerogen type analysis provides information on hydrocarbon source potential and depositional environment. Van Krevelen diagram can be used to determine the kerogen type by making cross-plot between Hydrogen Index versus Oxygen Index (Van Krevelen, 1961).

The Late Oligocene-Early Miocene Talang Akar Formation is composed by shale, rocks and sandstone, with the delta plain-prodelta facies, where the delta environment is an excellent environment for producing hydrocarbon. The Early Miocene-Middle Miocene Gumai Formation is composed by shale, limestone and sandstone, with shelf facies (Suhendan, 1984). This research evaluates Talang Akar Formation (Figure 1) as a potential and quality of source rock shale gas based on geochemical analysis.

\section{Stratigraphy of South Sumatra Basin}

The stratigraphy of the South Sumatra basin area is generally was control by process of megacycle system consisting of a transition and regression. Formations formed during the transgression phase are grouped into Telisa Groups (Talang Akar Formation, Baturaja Formation, and Gumai Formation). The Palembang group was deposited during the regression phase (Air Benakat Formation, Muara Enim Formation, and Kasai Formation), while the Lemat and older Lemat Formations were deposited before the main transgression phase. The 
stratigraphy of the South Sumatra Basin as follows (Figure 2).

Muara Enim Formation is marked by sandstone, claystone, siltstone, shale, and coal streak. The upper part dominated by claystone, siltstone with minor sandstone, and coal streak. Claystones are greenish grey to grey, soft, non-calcareous. Siltstones are greenish grey to light brown, blocky to platy, firm to medium hard, streak carbon. Sandstone are poor to medium porosity, greenish grey to grey, medium hard, fine to medium grain, medium sorted, sub-angular to sub rounded. Coal are black, brittle, wood texture, concoidal fracture. The lower part is dominated by shale, siltstone with minor claystone, sandstone, with coal streak. Shale is grey to light grey, soft, platy to sub fissy, no-calcareous. Siltstone are green grey to dark brown, firm to medium hard, fine to medium grain, sub angular to sub rounded, medium sorted (Barber, Crow, \& Milson, 2005; De Smet, 1992). The environment of deposition of the Muaraenim Formation is coastal and sediment composition includes sandstones with coal seams. The part where the member is thin, coal beds become very thin or are absent. This fact suggests that subsidence rates played an important role in coal deposition and preservation. The age of member has never been determined accurately, however, it should be within the Late Miocene-Early Pliocene.

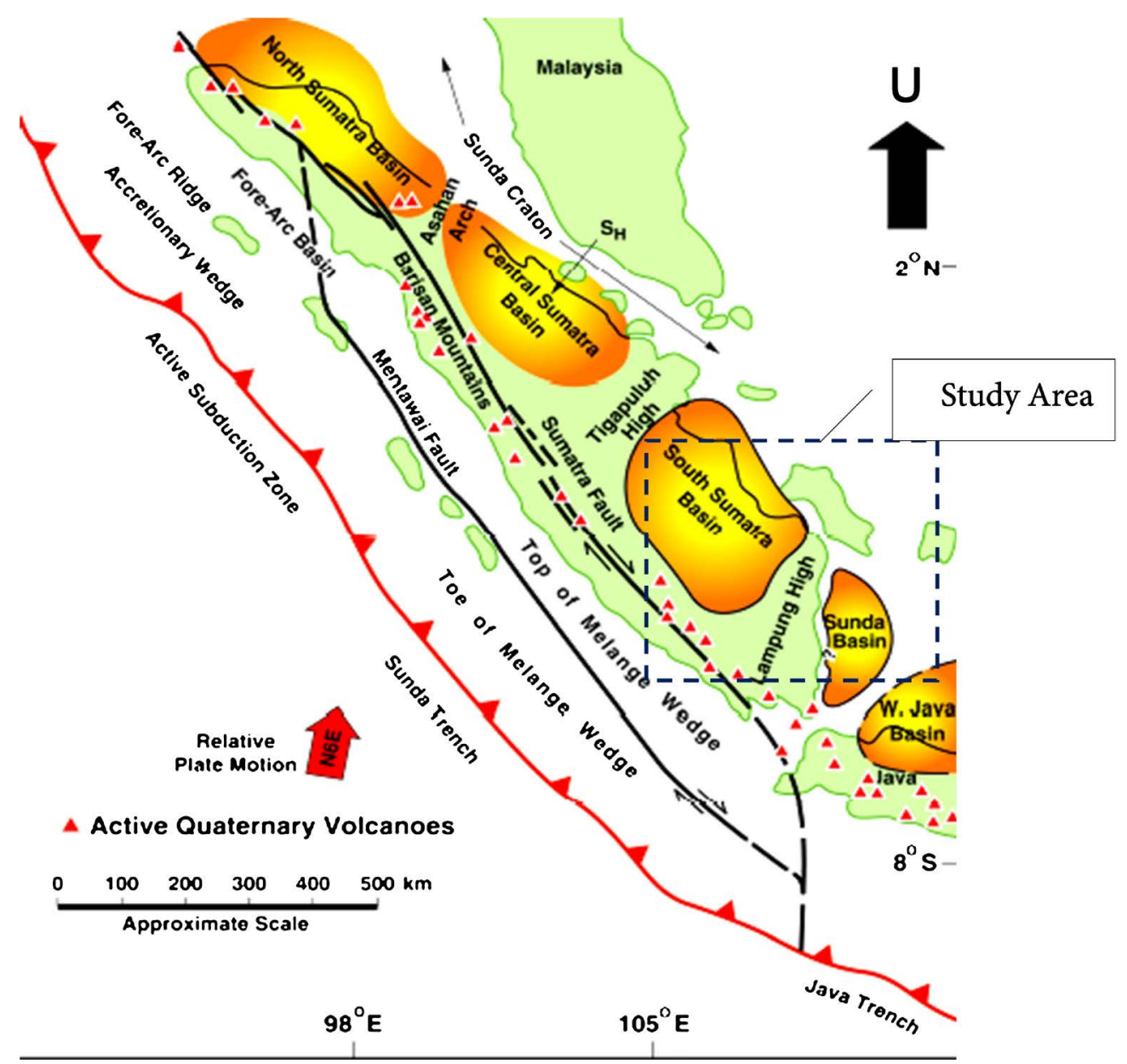

Figure 1. Location map of the study area (Heidrick \& Aulia, 1993). 


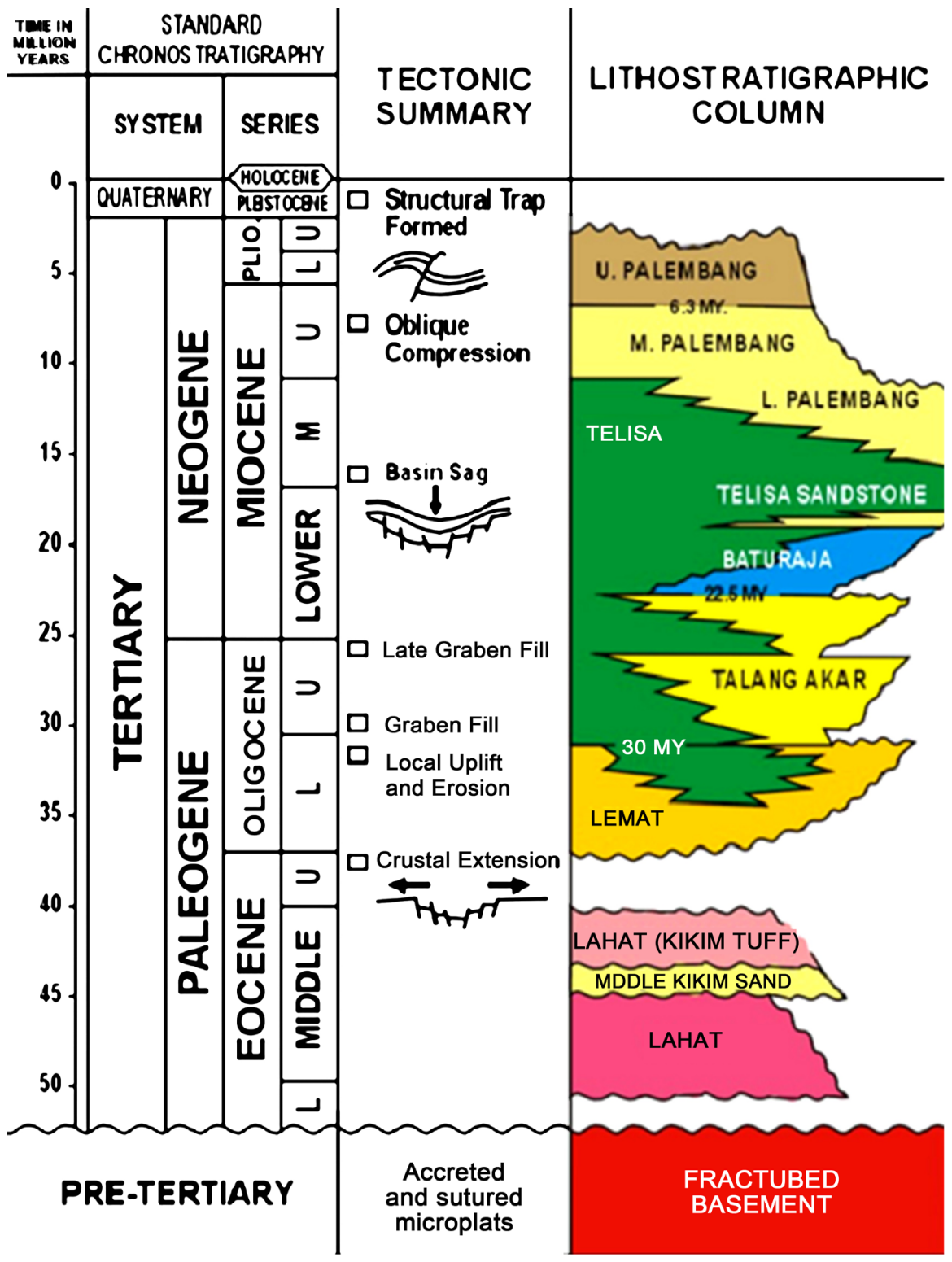

Figure 2. Stratigraphy of South Sumatra Basin (De Coster, 1974).

Air Benakat Formation is dominated by shale, siltstone minor claystone, and sandstone with coal streak. The upper part is dominated by shale, siltstone, claystone with sandstone, and coal streak. Shale are grey to light grey, soft to firm, occasionally carbon speek, non-calcareous. Siltstone are light grey, soft to firm, speek carbon, non-calcareous. Sandstone are poor porosity, soft to friable, sub rounded, medium sorted to poor sorted, fine to medium grain, and loose quartz. The Lower part is dominated by shale, sandstone and siltstone (Barber, Crow, \& Milson, 2005). Siltstone are grey to brown grey, soft to firm, platy, non to slight carbon. Sandstone are poor porosity, white, off white, light grey, fine grain, poor sorted to medium sorted, sub rounded to sub angular, calcareous, quartz, and glauconit. Siltstone are brown grey, soft to firm, speek carbon, non to slight calcareous, and sub blocky (Hutchison, 1996). 
Gumai Formation is dominated by shale with sandstone and siltstone streak. Marl is found in the Lower part. The Upper part is dominated by shale with sandstone and siltstone streak. Silt are grey to dark grey, soft to medium hard, platy, blocky, slight to non-calcareous. Sandstone are good porosity, white grey, medium to hard, medium grain, sub angular to sub rounded, medium sorted, calcareous cemented, quartz, and glauconit. The Lower part is dominated by shale sandstone and siltstone streak. Marl is found at the bottom. Shale are brown to dark grey, firm to medium hard, platy to sub platy, calcareous (Barber, Crow, \& Milson, 2005; De Smet, 1992). Sandstone are good porosity, light grey to green grey, medium hard, consolidated, very fine to fine grain, sub rounded, medium sorted, calcareous. Siltstone are light, medium hard, blocky, calcareous, traces carbon, sandy. Marl are white to light brown, medium to hard, and compact (Hutchison, 1996).

Batu Raja Formation is dominated by limestone with minor shale. Limestone are poor to medium porosity, white to light brown, soft, carbon speek, no oil slow. Shale are brownish grey to grey, medium hard to hard, blocky, and slight calcareous (Spruyt, 1956).

Talang Akar Formation (TRM) is dominated by shale, siltstone, sandstone, limestone streak, and coal. Coals are found along the Upper part to the bottom. The Upper part is composed by shale, sandstone and limestone streak. Sandstones are medium porosity, white to colored, fine to medium hard, fine to medium grain, sub rounded to sub angular, medium sorted, calcareous cemented, containing glauconite minerals. Shale are brown to brown grey, medium hard, blocky, slight calcareous cemented and trace carbonate speek. Siltstone are light grey to grey, medium hard, sandy, consolidated, slight calcareous, trace carbon speek. The bottom part is dominated by shale, sandstone, minor siltstone, and coal layer. Shale are brown to dark brown, medium hard, blocky to platy, non-calcareous, silty, carbonaceous. Sandstone are medium porosity, colored to off white, fine to medium grain, trace coarse grain, sub rounded, medium sorted, carbonate speek (Spruyt, 1956). Siltstone are brown to dark brown, friable to medium hard, blocky, non calcerous, carbonate streak, locally sandy. Coal are black, brittle, glassy luster. Oil show indications are often found in the Talang Akar Formation (TRM). All the oil show indications are found in sandstone at the depth of 1904, 2004 and $2100 \mathrm{~m}$ (Hartanto, Widianto, \& Safrizal, 1991).

Talang Akar Formation (Gritsand member) is dominated by sandtone, shale, siltstone, and coal streak. Oil show can be found at 2218, 2226, 2250, 2360, 2484, $2564,2620,2644,2684,2704,2780$, and $2798 \mathrm{~m}$, as much as $5 \%$ to $40 \%$. Shale are grey to light grey, medium hard, platy, silty, non to slight calcareous. Sandstone has medium to good porosity, colored to white, lost quartz, medium to coarse grain, sub angular to angular, medium sorted, locally coarse grain, non-calcareous (Hutapea, 1981). Siltstone are light grey, brown to dark brown, medium hard, and carbonaceous. The difference between Talang Akar's TRM and GRM are the sandstone texture (grain size). Talang Akar TRM is dominated by fine to medium grain, while Talang Akar GRM is dominated by medium to coarse grain 
(mainly coarse grain) (Jackson, 1960).

Lahat Formation is composed by shale, sandstone, siltstone, tuffaceous claystone, and breccia/conglomerate, and characterized by volcanic materials. Shale are brown to dark brown, medium to hard, commonly silty, carbonaceous, non-calcareous. Sandstone are medium porosity, light brown to brown, medium hard, consolidated, very fine to fine grain, medium sorted, quartz, silica cement, volcanic materials. Siltstone are gray, brown, soft, blocky, commonly carbonaceous (Jackson, 1960). Tuffaceous claystone are white, soft, locally silty to sandy, carbonaceous speek, tuffaceous. Breccia/conglomerate are medium porosity, light grey, fine to coarse grain, angular to sub angular, medium sorted, fragments: quartz, plagioclase, igneous rock materials, volcanic materials. Matrix include silica and cement include silica and tuffaceous (Eubank \& Makki, 1981).

\section{Analytical Methods}

A broad literature review was undertaken to understand the geology and petroleum system (source rock, reservoirs, seals, and traps) in the area. The geochemical data then become an important parameter in defining shale gas plays. The shale should meet two conditions, source as well as reservoir rock properties. The present study focuses mainly on the source rock properties. This research using by geochemical techniques i.e. TOC and Rock-Eval Pyrolysis to determine the amount of organic matter i.e. total organic carbon (TOC (wt\%), type of organic matter (Kerogen Type I, II, III), genetic potential (Hydrogen Index (HI); $\mathrm{mg} \mathrm{HC/g} \mathrm{C}$ and Oxygen Index (OI); $\mathrm{mg} \mathrm{CO}_{2} / \mathrm{g} \mathrm{C}$ ). 37 samples were collected from well cuttings in JML-1 and JML-2 wells. Samples we are received into the laboratories in the forms of well site canned ditch cuttings, bagged ditch cuttings in various stages of preparation from wet, unwashed to dried, washed; sidewall cores, conventional cores, outcrop samples. Each sample assigned a number which was entered into a computer system to monitor sample selection and progress. Preparation techniques we are directed towards obtaining clean samples, free of drilling mud and mud additive, obvious caving contamination and indeterminate fine material. TOC was measured from lab analysis. Kerogen type, maturity and genetic potential were also evaluated in laboratory by Rock-Eval pyrolysis. The Rock-Eval pyrolysis performed in the Lemigas Laboratory, was conducted on each sample following standard procedures.

\subsection{TOC Measurements in Laboratory}

Organic carbon values are obtained by treating $0.1 \mathrm{~g}$ of crushed rock sample with hot. TOC is measured in laboratory using LECO Carbon Determinator (WR-112). The standard procedure has been followed for TOC measurement. The TOC of rock sample was measured by combustion of organic matter under air or atmospheric oxygen at a temperature of $1200^{\circ} \mathrm{C}$ (LECO Induction Oven). Carbonates were separated by acid treatment (10\% HCL Solution), prior to combustion, to avoid the $\mathrm{CO}_{2}$ interference due to the decomposition of carbo- 
nates at elevated temperature.

\subsection{Rock-Eval Pyrolysis}

This analysis is used to identify type and maturity of shale material as well to detect the hydrocarbon content in the material. The already chosen and crushed dried samples were processed. For Rock-Evaluation, $\sim 100 \mathrm{mg}$ of pulverized sample was taken stainless steel crucibles. Then it was put into the Rock-Eval 6 instrument and heated to $300^{\circ} \mathrm{C}$ for 3 minutes. The free hydrocarbon evaporated and measured as $\mathrm{S} 1$ peak (mg HC/g of rock). Then the temperature was raised from $300^{\circ} \mathrm{C}-500^{\circ} \mathrm{C}$ at a heating rate of $25^{\circ} \mathrm{C}$ per minute. This is the evaporation phase of heavy hydrocarbon components and also the cracking phase of nonvolatile organic material (Hunt, 1996). The hydrocarbons released during this thermal cracking are obtained as S2 and at the peak, Tmax was noted. The $\mathrm{CO}_{2}$ released from cracking was heated and detected on a thermal conductivity detector (TCD) during the cooling of the pyrolysis oven corresponding to S3 peak.

\section{Results and Discussion}

In this study to evaluate the Talang Akar Formation for shale gas prospects using well cuttings. There are 2 (two) wells in the research area and each well has geochemical data. In addition, there are two wells used as the guidance, namely JML-1 and JML-2 wells. The depth of well JML-1 is $1998 \mathrm{~m}$ and JML-2 around $3144 \mathrm{~m}$. Kerogen type, maturity and genetic potential were also evaluated in lab by Rock Eval Pyrolysis. Table 1 shows the analytical results of geochemical analysis and pyrolysis measurements of the rock samples.

\subsection{Quality and Quantity of Organic Matter}

The analyzed sedimentary rocks are light gray to dark gray, non-calcareous to calcareous, and some silty. The level of color and composition of the rock is generally relevant to the composition value of the organic material. The darker the color of the rock the more organic material the rocks have. Analysis results of 37 samples in term of organic matter richness show a TOC value ranged from $0.18 \mathrm{wt} \%-6.12 \mathrm{wt} \%$.

Based on the classification of Peters and Cassa (1994), at the JML-1 the shale rock of Talang Akar Formation (TAF) divided into 4 (four) categories: 1) Fair source rock; 2 samples with a TOC compositions ranging from 0.72 wt $\%$ to 0.95 wt\%; 2) Good source rock; 8 shale samples fall in this category where TOC ranging from $1.04 \mathrm{wt} \%$ to $1.53 \mathrm{wt} \%$; 3) Very good source rock; represented by 8 samples with a TOC composition of $2.34 \mathrm{wt} \%$ to $3.98 \mathrm{wt} \%$ and iv). Excellent source rock; 7 samples are categorized as excellent source rock, whose TOC compositions ranging from $4.13 \mathrm{wt} \%$ to $6.12 \mathrm{wt} \%$. The overall TOC analysis can be interpreted that these samples have an average organic richness in the range of good to excellent source rock (TOC: $0.72 \mathrm{wt} \%-4.85 \mathrm{wt} \%$ ). The exception is seen at the depth interval between 1625 m - 1990 m (Talang Akar Formation), 
Table 1. TOC and Rock-Eval pyrolysis result from the sampled rock.

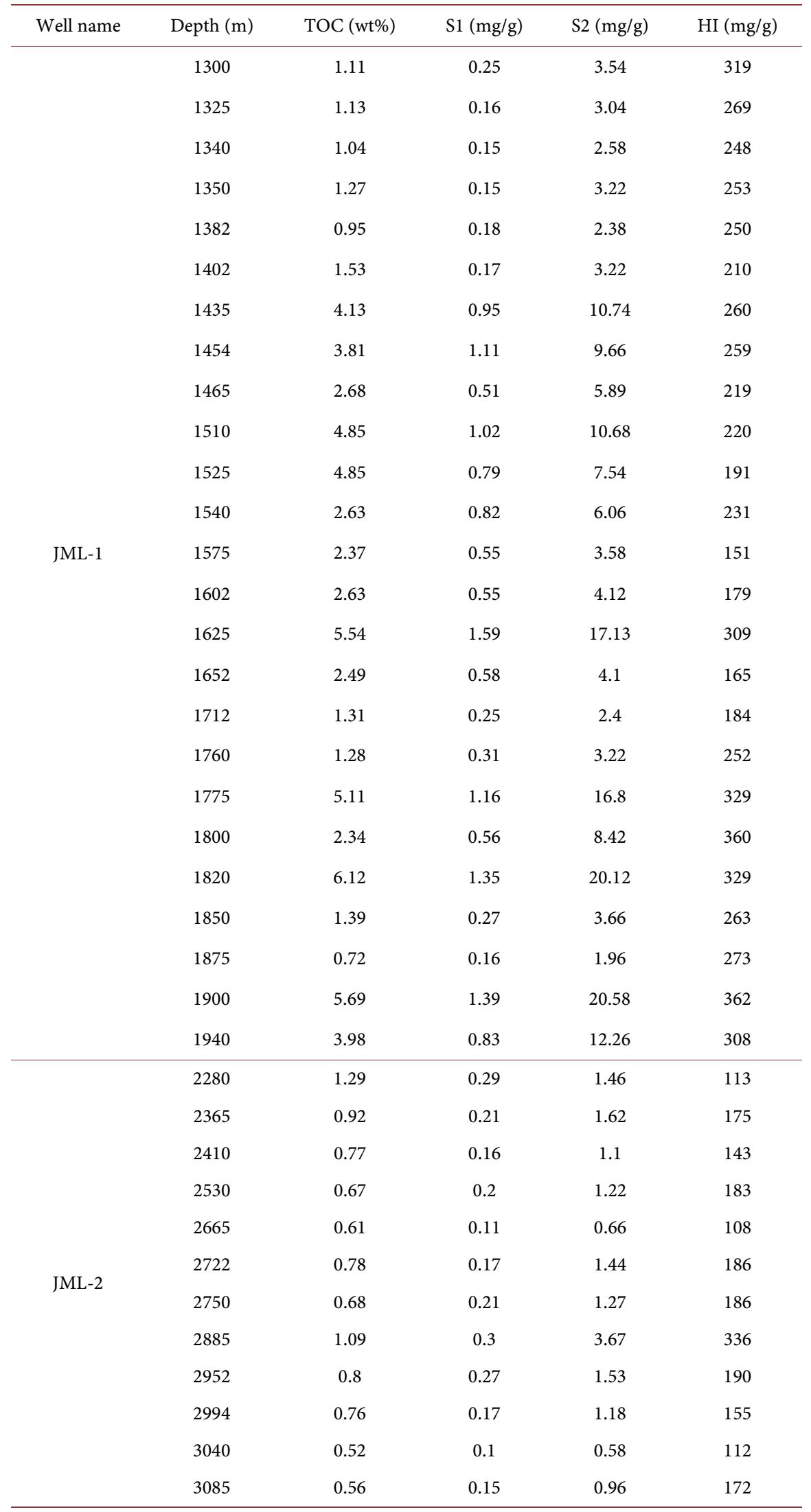


which has the richest organic material (excellent) with TOC content $>4 \mathrm{wt} \%$.

While at JML-2 well, we have i). Fair source rock; 10 samples categorized as fair having TOC's values ranging from $0.52 \mathrm{wt} \%-0.92 \mathrm{wt} \%$ and ii). Good source rock; 2 samples categorized as good have TOC's values ranging from $1.09 \mathrm{wt} \%$ $1.29 \mathrm{wt} \%$. The organic carbon data of analyzed shales showed a range of numbers between $0.37 \mathrm{wt} \%-1.29 \mathrm{wt} \%$ TOC where the lowest values were found in the sediments from 3105 - $2280 \mathrm{~m}$. Determination of potential source rocks based on the value of organic carbon content shows that only two shales from $2280 \mathrm{~m}$ depth and $2885 \mathrm{~m}$ fall in the good as source rock category. Other shale samples with an organic carbon value of $<1 \%$ can be potentially considered as poor to fair source rock.

In the play concept of shale gas, using the shale-gas data that have been successful in America, the minimum average TOC value required is 2 . The minimum value of shale-gas TOC is different from the conventional play concept because to produce enough gas and get stuck in the shale rock, more organic rich material is required.

The S1 parameter is the free hydrocarbon, the hydrocarbon and oxygen compounds contained in the rock, expressed in $\mathrm{mg} \mathrm{HC/g}$ (sourced from pyrolysis analysis). The S2 parameter is the potential of extractable hydrocarbon, in $\mathrm{mg}$ $\mathrm{HC} / \mathrm{g}$ or in this case, the peak S2 shows the presence of potential hydrocarbons in the rock and its maximum temperature is the $\operatorname{Tmax}\left({ }^{\circ} \mathrm{C}\right)$ parameter in pyrolysis. Production Yield (PY) is the total of S1 and S2 parameters in $\mathrm{mg} \mathrm{HC/g}$, which aims to determine the production of hydrocarbons in rocks (Peters \& Cassa, 1994).

The plot of TOC versus Rock-Eval pyrolysis S2 was interpreted to determine the type of organic matter (Figure 3 ). The figure shows that samples are of mix type II/III and type III kerogen. A source rock capable of producing gas and gas/oil. The potential source rock facies are dominated by type II/III kerogens derived from higher plant material, with minor liptinite and alginite components.

The comparison of production indices with the thermal maturity stage of samples was used to identify migrated hydrocarbon (Hunt, 1996). The high S1 values are either: 1) normal, which indicate prospective source rock; or 2) abnormal, resulting from a combination with migrated oil, or coming from drilling additives (Peters \& Cassa, 1994). When S1 is high and TOC is low, non-indigenous hydrocarbon can be detected (Hunt, 1996). On the other hand, the plot of S1 versus TOC (Figure 4) can be used to discriminate between non-indigenous (allochthonous) and indigenous hydrocarbons (autochthonous). This relation shows that majority of the studied rock samples from JML-1 and JML-2 wells were characterized by indigenous hydrocarbons (autochthonous) indicative of dry gas generation window.

Based on the classification of [2] in the JML-1, there are three shale samples categorized as poor compositions of S2 or kerogen, ranging from 1.96 to 2.4 


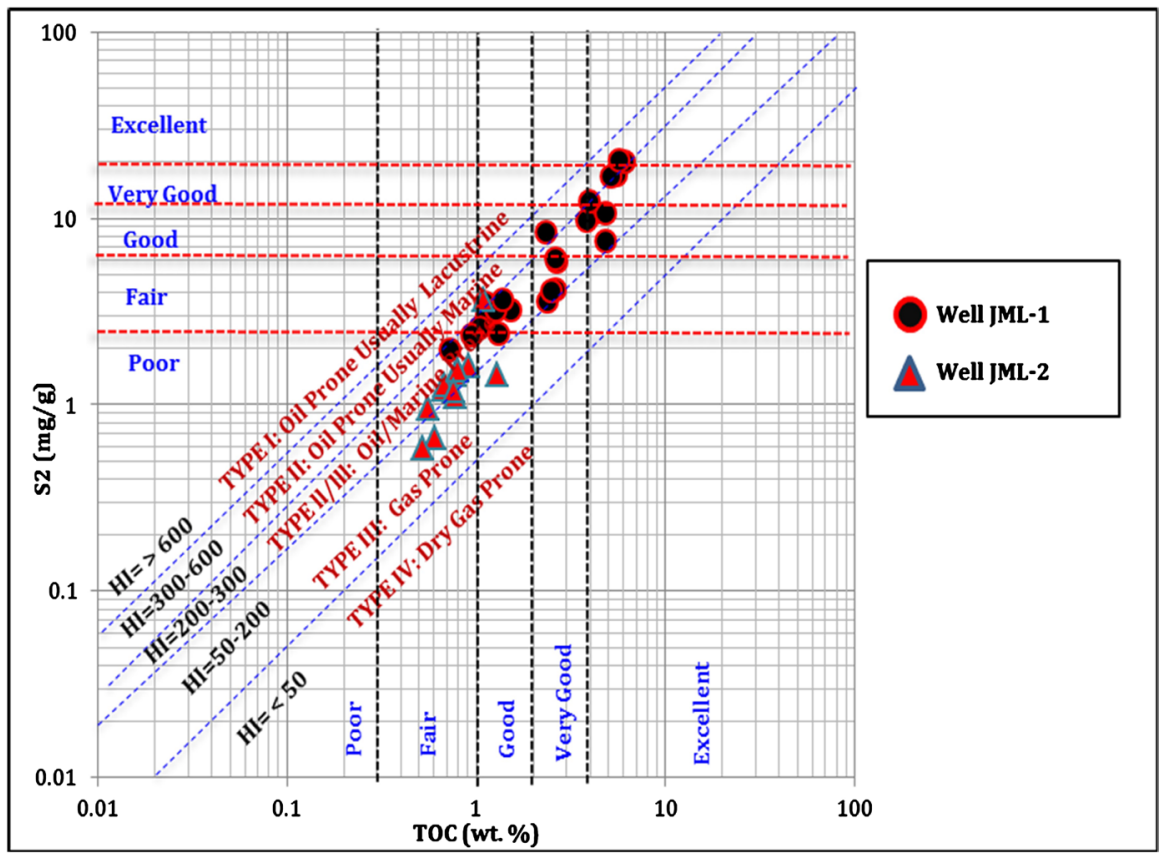

Figure 3. Crossplot of remaining hydrocarbon potential (S2) and TOC (wt\%). All the samples are falling in type II/III and III zones.

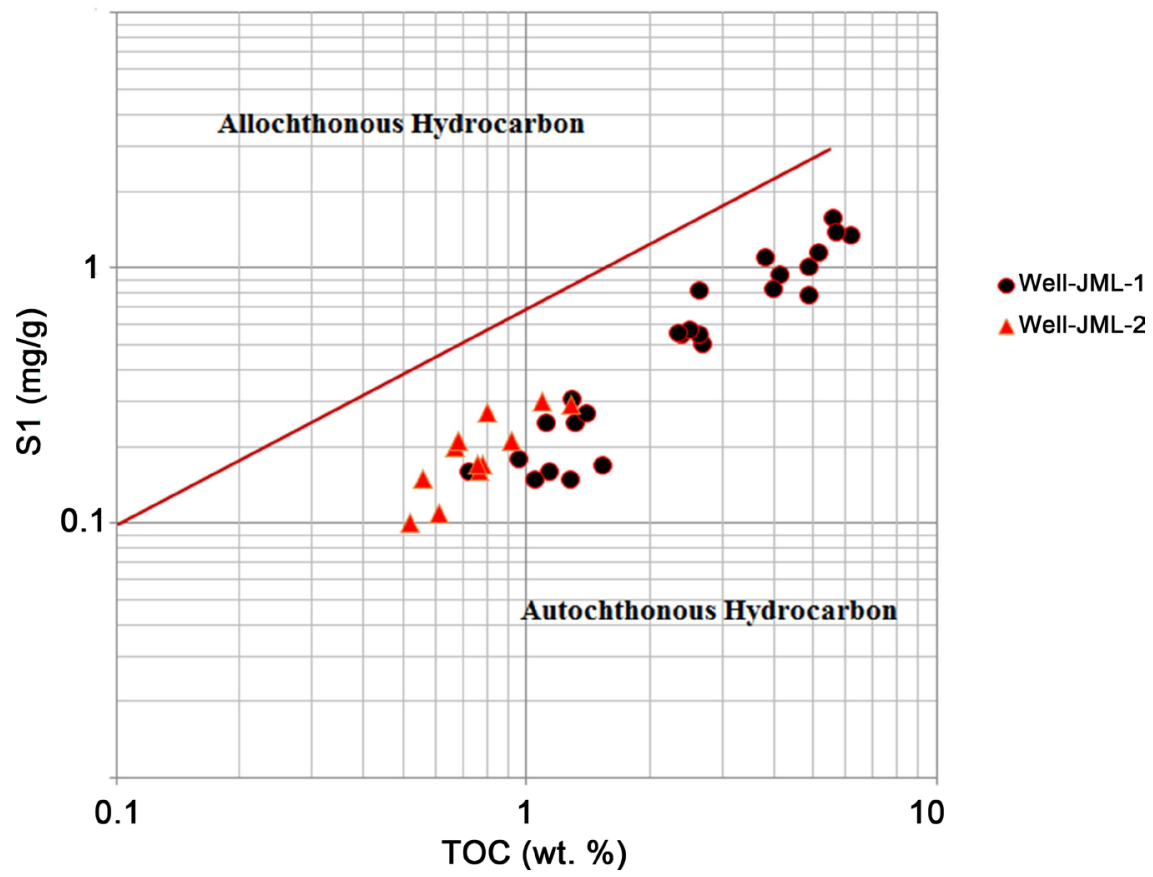

Figure 4. S1 versus TOC (wt\%) crossplot shows all the samples are in the zone of nonindigenous hydrocarbon.

$\mathrm{mg} / \mathrm{g}$, making it less likely to produce hydrocarbons at the thermal maturity level. Ten samples of shale are categorized as fair compositions of S2 or kerogen ranging from $2.58-4.12 \mathrm{mg} / \mathrm{g}$, so that it has the potential to produce hydrocarbons at the level of thermal maturity. Five samples of shale are categorized as good composition of S2 with a value of $5.89-9.66 \mathrm{mg} / \mathrm{g}$, so it is potentially good 
for producing hydrocarbons at the level of thermal maturity. Five samples of shale are categorized very good composition of S2 with $10.68-17.13 \mathrm{mg} / \mathrm{g}$, so it has good potential to produce hydrocarbon at thermal maturity level and two samples of shale are categorized excellent composition of S2 with value 20.12 $20.58 \mathrm{mg} / \mathrm{g}$. Rock eval pyrolysis conducted on 25 samples at $1300 \mathrm{~m}-1940 \mathrm{~m}$ depth shows that the analyzed samples have a poor to very good potential. The sample interval with very good classification is encountered at a depth of 1435 m, $1510 \mathrm{~m}$ for Talang Akar Transitional Member (TRM) Formation and $1625 \mathrm{~m}$, $1750 \mathrm{~m}, 1820 \mathrm{~m}, 1900 \mathrm{~m}$, and $1940 \mathrm{~m}$ formations for Talang Akar Gritsand Member (GRM) Formation. The $1750 \mathrm{~m}$ interval shows the largest content of all samples analyzed, while the free hydrocarbon content of all analyzed samples generally falls into the fair category except at $1750 \mathrm{~m}$ intervals showing the best data. Pyrolysis data generally show that most of the hydrocarbons in the analyzed samples are still bound to kerogen.

In the JML-2 well there are eleven shale samples categorized as poor compositions of S2 having values ranging from 0.58 to $1.62 \mathrm{mg} / \mathrm{g}$ so that it is less potent to produce hydrocarbons at a good thermal maturity level and one sample is categorized as fair composition of S2 which range from $3.67 \mathrm{mg} / \mathrm{g}$ so that it has the potential to produce hydrocarbons at a mature thermal maturity level. Determination of hydrocarbon potential from the sediments of the Talang Akar Formation is done with the assumption that no primary migration has been formed out of source rock.

\subsection{Genetic Type of Organic Matter}

Analysis of organic material type is the basic nature of petroleum products, namely oil or gas. Organic material in the source rock which produces oil or gas in certain qualified conditions is called kerogen. To classify the type of kerogen, the usual method is to create a graph between the hydrogen index and the oxygen index, or a comparison between the hydrogen index and Tmax values can be used. We have previously discussed the analysis of organic richness materials based on TOC parameters.

The initial genetic type of organic matter of a particular source rock is essential to produce oil and gas. Waples (1985) used the hydrogen index (HI) value to differentiate between the types of organic matter. Hydrogen indices $<150 \mathrm{mg}$ $\mathrm{HC} / \mathrm{g}$ indicate a potential source to generate gas (mainly type III kerogen). Hydrogen indices value in the range of $150-300 \mathrm{mg} \mathrm{HC} / \mathrm{g}$ contain more type III kerogen than type II and therefore are capable of generating mixed oil and gas but mainly gas. Kerogen with hydrogen index $>300 \mathrm{mg} \mathrm{HC} / \mathrm{g}$ contains a substantial amount of type II macerals and thus are considered as a good source rock capable of to producing oil and minor gas. Kerogen with hydrogen index > $600 \mathrm{mg} \mathrm{HC/g}$ usually indicate to nearly type I or type II kerogen and have an excellent potential to generate oil (Waples, 1985).

The HI data confirm a gas prone source in the Talang Akar unit. Given the 
low HI values, there existed the effects of weathering on source rocks. In this case, the Talang Akar succession may have undergone any surface weathering since the commencement of basin inversion following the Late Neogene orogeny (Doust \& Noble, 2008).

The organic rich shale is identified as fine grain clastic sediments that have a TOC greater than two percent, an HI greater than 100 and clay volumes greater than fifty percent. Gas prone shales are distinguished from oil prone shales by selecting organic rich shales with $\mathrm{HI}$ less than $300 \mathrm{mg} \mathrm{HC} / \mathrm{g}$.

Based on Figure 5, the potential shale at the JML-1 is approximately located at $1652 \mathrm{~m}$ depth containing gas and about $1820 \mathrm{~m}$ depth containing oil because it has entered the early maturity phase which has high shale maturity value (Tmax and Ro). The JML-2 has entered the early to late maturity phase and, the shale gas potential is higher at a depth of $2280-3085 \mathrm{~m}$, based on the shale maturity value (Tmax and Ro). Kerogen composition is also influenced by the thermal process, namely catagenesis and metagenesis, which alters the kerogen. Underwater heating causes chemical reactions that break up small fragments of kerogen into oil. The residual kerogen also undergoes a change that is reflected in its chemical and physical conditions. The history of diagenesis and catagenesis and the natural condition of the organic material of its constituents greatly influence kerogen's ability to produce oil and gas.

HI versus Tmax crossplot (Figure 6.) was analysed for kerogen type determination (Hunt, 1996). It shows that the kerogen type in both wells is type II-III of the kerogen, so it can be used as a potential source rock forly gas or mixed oil and gas. Kerogen type II can be derived from several sources including: marine algae, pollen and spores, plant wax layers, fossil resins, and plant fats. Kerogen type II is often found in marine sediments under reduced conditions. Kerogen type III consists of terrestrial organic materials containing only small amount of fats or waxy substances.

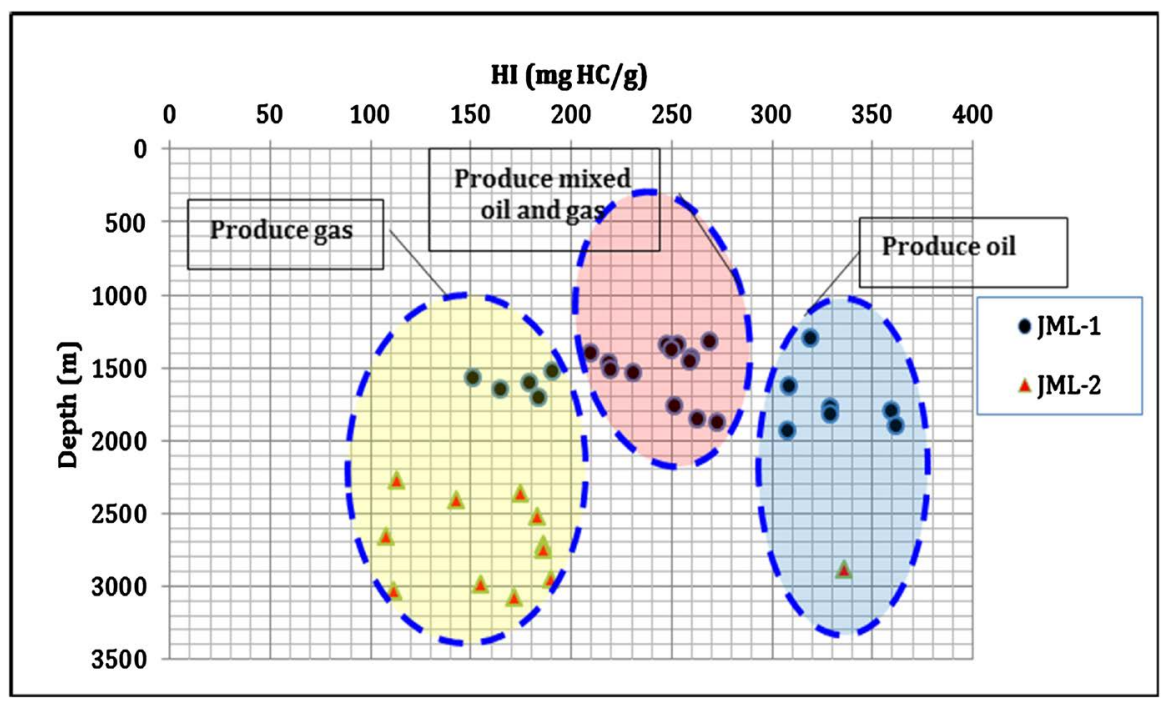

Figure 5. Crossplot between values of HI versus depth in JML-1 and JML-2 wells. 
Tmax vs Hydrogen Index (HI)

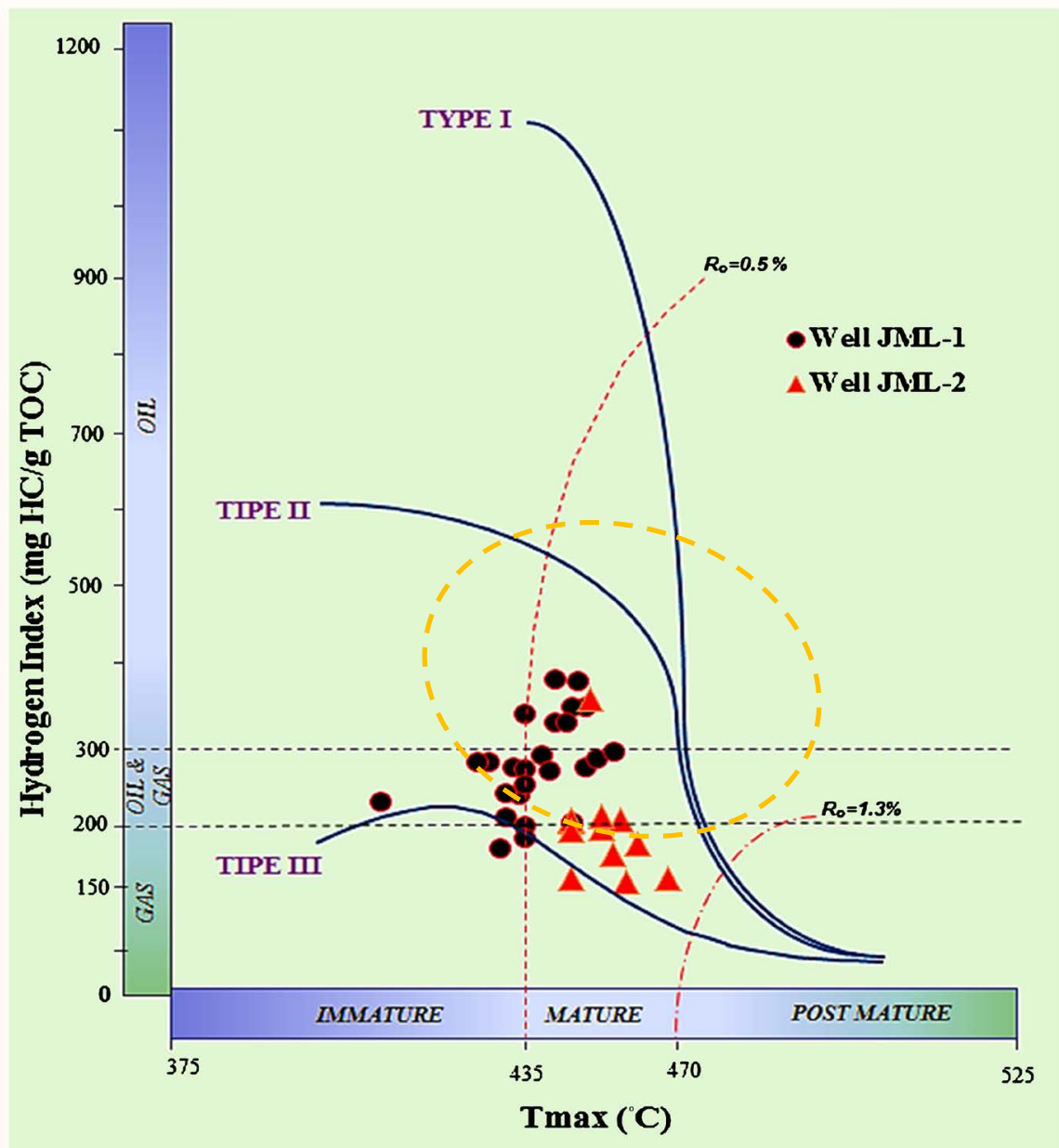

Figure 6. Crossplot HI versus Tmax in JML-1 and JML-2 wells. The plot shows kerogen type and maturity range of the samples (Van Krevelen, 1961).

Cellulose and lignin are the largest contributors to Type III of the kerogen. This type has a lower production capacity of liquid hydrocarbons than kerogen II, and if without a mixture of the type-II kerogen, this type only produces natural gas. Determination of kerogen type or quality of sediment from Talang Akar Formation is carried out using microscopic observation in the form of kerogen composition. Microscope observation data showed that kerogen is dominated by organic humic-vitrinitic material. Nevertheless, the analyzed HI values of the samples show the highest value at a depth of $2885 \mathrm{~m}(\mathrm{HI}=336)$ which indicated the presence of liptinitic kerogen (Type II) indicating oil forming capacity. The other shales of Talang Akar Formation contain Vitrinite (Type III) kerogen shown by HI values between 112 and 190 and have the optimum potential of producing gas condensate.

\subsection{Generating Potentialities}

The generation potential of a source rock is identified using the results of pyro- 
lysis analysis. The genetic potential (GP) is the sum of the values $\mathrm{S} 1$ and $\mathrm{S} 2$. According to Hunt (1995), source rocks with a GP $<2$, from 2 to 5 , from 5 to 10 and $>10$ are considered to have poor, fair, good, and very good generation potential (Hunt, 1996). Figure 7 shows that the source rock in JML-1 are considered as fair to very good source except few samples that are considered as good source potential.

According to Perbawa, Kusuma, and Winardhi (2012), the potential shale gas has a thick mudstone of interval about $100 \mathrm{ft}$ and has TOC $>1 \%$ is in the Upper Talang Akar Fm. The Lower Talang Akar Formation has less potential shale gas. The shale that has TOC $>1 \%$ is thin and has several intercalations with sandstone (Perbawa, Kusuma, \& Winardhi, 2012).

\section{Conclusion}

This study evaluates the Talang Akar Formation for shale gas reservoir in terms of its Total Organic Carbon (TOC), generation potential, maturity, subsurface depth and thickness. This formation is already a potential reservoir in South Palembang sub-basin. It was deposited in various sedimentary environments, from fluvial environment (terrestrial), transitional environment until shallow marine environment. We found that TAF is rich in organic matter with TOC ranging from $0.52 \mathrm{wt} \%$ to $6.12 \mathrm{wt} \%$ (fair to excellent criteria). Typical oil and gas generating potential is anticipated from the sediments with hydrogen indices (HI) from 108 to $362 \mathrm{mg} \mathrm{HC/g}$ TOC. Given the low HI values, there exist the effects of weathering on source rocks. It has also been confirmed with the results of

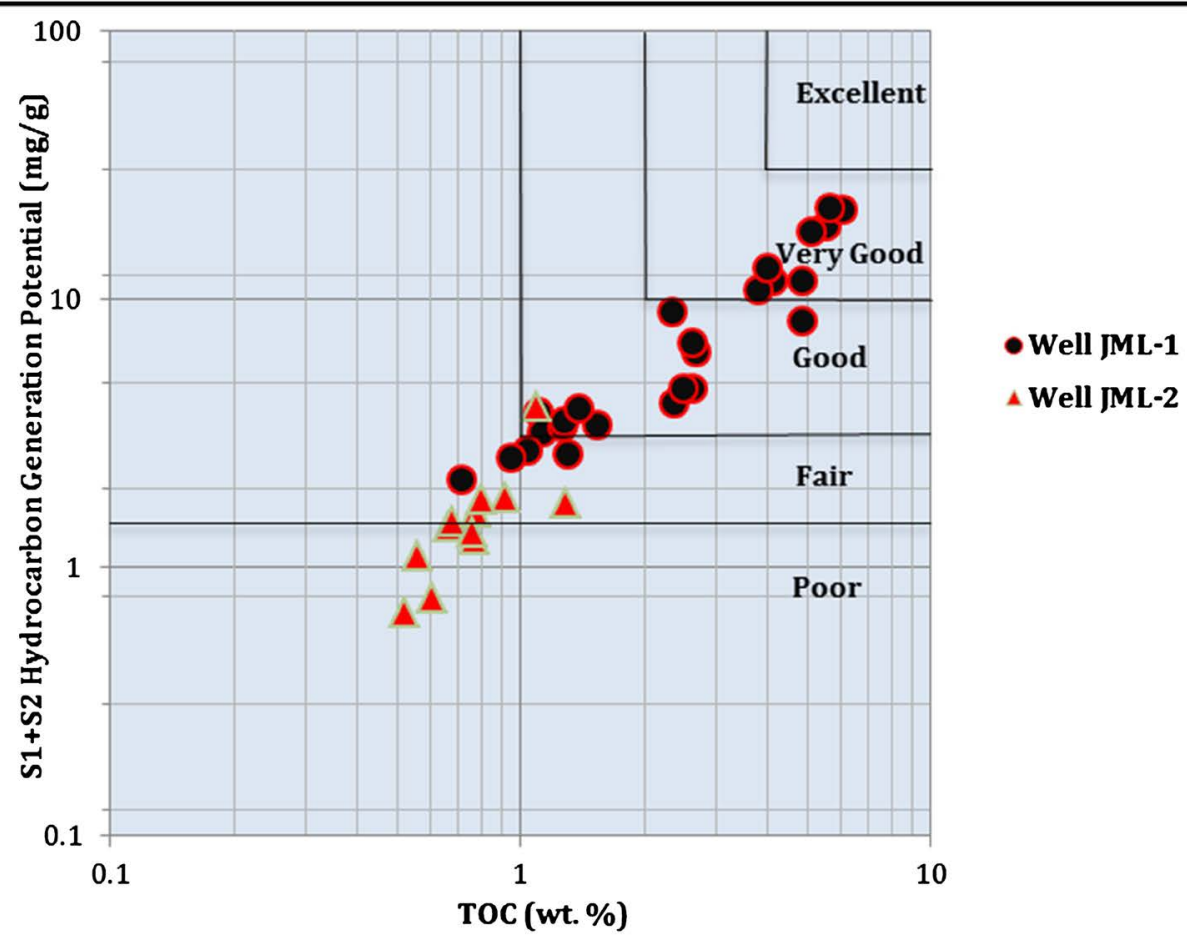

Figure 7. Cross-plots of genetic ration potential (GP) versus TOC. 
cross-plot between Hydrogen Index (HI) with Tmax, Talang Akar Formation producing type II/III kerogen. In this case, the Talang Akar succession may have undergone any surface weathering since the commencement of basin inversion following the Late Neogene orogeny. But overall, the Talang Akar Formation has the potency to be developed as shale gas reservoir.

\section{Acknowledgements}

We are grateful to the management of LEMIGAS R \& D Centre for Oil and Gas Technology, Indonesia for granting permission to use data and to present this paper. We are strongly thankful to all faculty members of Department of Petroleum Geology, China University of Petroleum (East China) for their co-operation.

\section{Conflicts of Interest}

The authors declare no conflicts of interest regarding the publication of this paper.

\section{References}

Barber, A. J., Crow, M. J., \& Milson, J. S. (2005). Sumatra: Geology, Resource and Tectonic Evolution. Geological Society of London, 31.

Courteney, S., Cockcroft, P., Lorentz, R., Miller, R., Ott, H. L., Prijosoesilo, P., Shendan, A. R., \& Wight, A. W. R. (1990). Indonesia-Oil and Gas Fields Atlas Volume III: South Sumatra. Indonesia: Indonesian Petroleum Association Professional Division.

De Coster, G. L. (1974). The Geology of the Central and South Sumatra (pp. 77-110). Indonesian Petroleum Association $3^{\text {rd }}$ Annual Convention.

De Smet, M. E. M. (1992). A Guide to the Stratigraphy of Sumatra, Tertiary. The Geology of the Central and South Sumatra Basins. Internal Report University of London Consortium for Geological Research in Southeast Asia (Unpublished).

Doust, H., \& Noble, R. A. (2008). Petroleum Systems of Indonesia. Marine and Petroleum Geology, 25, 103-129. https://doi.org/10.1016/j.marpetgeo.2007.05.007

Eubank, R. T., \& Makki, A. C. (1981). Structural Geology of the Central Sumatra Back-Arc Basin. Indonesian Petroleum Association $10^{\text {th }}$ Annual Convention. https://doi.org/10.29118/IPA.203.153.196

Hartanto, K., Widianto, E., \& Safrizal (1991). Hydrocarbon Prospect Related to the Local Unconformities of the Duang Area, South Sumatra Basin (pp. 17-36). Indonesian Petroleum Association $20^{\text {th }}$ Annual Convention.

Heidrick, T. L., \& Aulia, K. (1993). A Structural and Tectonic Model of the Coastal Plains Block, Central Sumatra Basin, Indonesia. Indonesian Petroleum Association, $22^{\text {nd }}$ Annual Convention, IPA 93-1.1-179 Jakarta. https://doi.org/10.29118/IPA.572.285.317

Hunt, J. M. (1996). Petroleum Geochemistry and Geology (2nd ed., 743 p.). New York: W.H Freeman.

Hutapea, O. M. (1981). The Prolific Talang Akar Formation in Raja Field, South Sumatra (pp. 251-268). Indonesian Petroleum Association, Proceedings of the $10^{\text {th }}$ Annual Convention. https://doi.org/10.29118/IPA.1889.250.267

Hutchison, C. S. (1996). South-East Asian Oil, Gas, Coal and Mineral Deposits. Oxford: Clarendon Press.

Jackson, A. (1960). Notes on a Regional Isopach Map of the Talang Akar Formation in 
South Sumatra. EP-31795 (Unpublished).

Perbawa, A., Kusuma, B., \& Winardhi, S. (2012). Integration of Seismic Inversion, Pore Pressure Predicyion and TOC Prediction in Preliminary Study of Shale Gas Exploration. $37^{\text {th }}$ HAGI Annual Convention and Exhibition, Palembang.

Peters, K. E., \& Cassa, M. R. (1994). Applied Source Rock Geochemistry. AAPG, 60, 93-120.

Spruyt, J. M. (1956). Subdivision and Nomenclature of the Tertiary Sediments of the Palembang-Jambi Basin. EP-27168 and EP-27168B (Unpublished).

Suhendan, A. R. (1984). Middle Neogene Depositional Environments in Rambutan Area, South Sumatra (pp. 63-73). Indonesian Petroleum Association $13^{\text {th }}$ Annual Convention. https://doi.org/10.29118/IPA.155.63.73

Van Krevelen, D. W. (1961). Coal: Typology-Chemistry-Physics-Constitution. Amsterdam: Elsevier Science.

Waples, D. (1985). Geochemistry in Petroleum Exploration. Boston: International Human Resources Development Corporation. https://doi.org/10.1007/978-94-009-5436-6 